\title{
Oxygen penetration deep into the sediment of the South Pacific gyre
}

\author{
J. P. Fischer ${ }^{1}$, T. G. Ferdelman ${ }^{1}$, S. D'Hondt ${ }^{2}$, H. Røy ${ }^{3}$, and F. Wenzhöfer ${ }^{1}$ \\ ${ }^{1}$ Max Planck Institute for Marine Microbiology, Bremen, Germany \\ ${ }^{2}$ Graduate School of Oceanography, University of Rhode Island, USA \\ ${ }^{3}$ Center for Geomicrobiology, University of Aarhus, Denmark
}

Received: 3 March 2009 - Published in Biogeosciences Discuss.: 19 March 2009

Revised: 23 July 2009 - Accepted: 30 July 2009 - Published: 7 August 2009

\begin{abstract}
Sediment oxygen concentration profiles and benthic microbial oxygen consumption rates were investigated during an IODP site survey in the South Pacific Gyre. Primary production, particle fluxes and sedimentation rates are extremely low in this ultra-oligotrophic oceanic region. We derived $\mathrm{O}_{2}$ consumption rates from vertical oxygen profiles in sediments obtained on different spatial scales ex situ (in piston cores and multi cores), and in situ (using a benthic lander equipped with a microelectrode profiler). Along a transect in the area 24 to $46^{\circ} \mathrm{S}$ and 165 to $117^{\circ} \mathrm{W}$, cores from 10 out of 11 sites were oxygenated over their entire length (as much as $8 \mathrm{~m}$ below seafloor), with deep $\mathrm{O}_{2}$ concentrations $>150 \mu \mathrm{mol} \mathrm{L}^{-1}$. This represents the deepest oxygen penetration ever measured in marine sediments. High-resolution microprofiles from the surface sediment layer revealed a diffusive oxygen uptake between 0.1 and $1.3 \mathrm{mmol} \mathrm{m}^{-2} \mathrm{~d}^{-1}$, equal to a carbon mineralization rate of $\sim 0.4-4.5 \mathrm{gC} \mathrm{m}^{-2} \mathrm{yr}^{-1}$. This is in the lower range of previously reported fluxes for oligotrophic sediments but corresponds well to the low surface water primary production. Half of the pool of reactive organic matter was consumed in the top $1.5-6 \mathrm{~mm}$ of the sediment. Because of the inert nature of the deeper sediment, oxygen that is not consumed within the top centimeters diffuses downward to much greater depth. In deeper zones, a small $\mathrm{O}_{2}$ flux between 0.05 and $0.3 \mu \mathrm{mol} \mathrm{m}{ }^{-2} \mathrm{~d}^{-1}$ was still present. This flux was nearly constant with depth, indicating extremely low $\mathrm{O}_{2}$ consumption rates. Modeling of the oxygen profiles suggests that the sediment is probably oxygenated down to the basalt, suggesting an oxygen flux from the sediment into the basaltic basement.
\end{abstract}

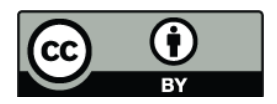

Correspondence to: J. P. Fischer (jfischer@mpi-bremen.de)

\section{Introduction}

Interpretation of sediment oxygen profiles is a common way to assess benthic carbon cycling since oxygen consumption rates correlate well with remineralization rates in sediments (Bender and Heggie, 1984; Thamdrup and Canfield, 2000). Oxygen concentration profiles thus contain information about the magnitude and vertical organization of carbon turnover. The depth of the oxic-anoxic interface is regulated by the balance between oxygen consumption (aerobic respiration and re-oxidation of the reduced products from anaerobic metabolism) and oxygen transport from the water column (diffusion, advection, bio-irrigation) (Glud, 2008). Due to the low flux of particulate organic matter from the photic zone to the seafloor in ocean gyres, only low rates of carbon mineralization can be sustained, and therefore, deep oxygen penetration can be expected. Wenzhöfer et al. (2001) found an oxygen penetration depth of $\sim 25 \mathrm{~cm}$ in the central South Atlantic. Earlier studies in the central Pacific found oxygen concentrations decreasing with depth only in the top layer and showing very little change with depth below $20-40 \mathrm{~cm}$ (Murray and Grundmanis, 1980).

The South Pacific gyre (SPG) is the largest oligotrophic marine environment on earth (Claustre and Maritorena, 2003). It is farther away from continents than any other oceanic region, and hence, it has very little aeolian and fluviatile input. The surface water of the SPG is characterized by chlorophyll concentrations below $20 \mu \mathrm{g} \mathrm{m}^{-3}$ (Ras et al., 2008) and these waters are among the clearest on earth in terms of UV absorption (Morel et al., 2007). The low surface water productivity results in low sedimentation rates that vary between 0.08 and $1.1 \mathrm{~mm} \mathrm{kyr}^{-1}$ (D'Hondt et al. 2009). In general, sediments of the SPG have received little scientific interest since the 1901 expedition of the S. S. Brittania described them as oceanic red-clays with manganese nodules. The whole area is understudied compared to other oceanic regions (Daneri and Quinones, 2001) and little is

Published by Copernicus Publications on behalf of the European Geosciences Union. 
known about the carbon cycle in the seabed. Since the overall area of oligotrophic subtropical gyres represents up to $60 \%$ of the global oceans (Claustre et al., 2008), their importance is evident. A recent study by D'Hondt et al. (2009) provides evidence that SPG sediments harbor subseafloor communities where microbial cell abundances are orders of magnitude lower than in all previously described subseafloor environments at the respective subseafloor depths. D'Hondt et al. (2009) used deep penetrating oxygen profiles coupled with pore water distributions of electron acceptors and metabolic products to demonstrate that extremely low aerobic metabolic activities occur throughout the SPG sediments. In this study, we more carefully investigate those deep oxygen profiles, combine them with microprofiles of the top sediment layer and explore these data in terms of depth-resolved oxygen consumption rates via mathematical modeling.

To investigate the oxygen flux in oligotrophic sediments, in situ and ex situ measurements with microsensors were performed using a free-falling benthic lander (Reimers et al., 1986; Wenzhöfer and Glud, 2002) and a multi-coring device, respectively. The high-resolution $\mathrm{O}_{2}$ profiles obtained from the uppermost active first centimeters were used to calculate the diffusive oxygen uptake of the sediment. Additionally, a special set-up for onboard measurements of oxygen concentrations in long piston and gravity cores was developed. Combining these methods enabled an integrated picture of the respiration rates in the first decimeters of the sediment down to several meters. Extrapolating the profiles down to the basalt and the application of a reactiondiffusion model gave further insight into $\mathrm{O}_{2}$ consumption in deeper layers. The rates of benthic carbon mineralization of the ultra-oligotrophic sediments of the SPG are discussed in comparison to other oligotrophic environments.

\section{Material and methods}

\subsection{Study site}

During the KNOX-02RR expedition (17 December 200627 January 2007), we sampled sediment cores at 11 stations within the region $24^{\circ} \mathrm{S}$ to $46^{\circ} \mathrm{S}$ and $165^{\circ} \mathrm{W}$ to $117^{\circ} \mathrm{W}$ (Fig. 1). The cruise track can be divided into two transects. A northern transect at a latitude of $24^{\circ} \mathrm{S}$ to $27^{\circ} \mathrm{S}$, proceeds from older crust $(\sim 100 \mathrm{Ma})$ to younger $(\sim 6 \mathrm{Ma})$ and at the same time from the outer portion of the gyre to its center. The southern transect at latitude of $38^{\circ} \mathrm{S}$ to $45^{\circ} \mathrm{S}$ leads out of the gyre towards older crust $(\sim 75 \mathrm{Ma})$ (Fig. 1$)$. Bottom water temperatures in this region are between 1.2 and $1.4^{\circ} \mathrm{C}$, the salinity is 34.7 and bottom water oxygen content is $\sim 220 \mu \mathrm{mol} \mathrm{L}^{-1}$ (derived from the database of the International Council for the Exploration of the Sea, ICES) which corresponds to $63 \%$ saturation at the sea surface (Weiss, 1970). To gain a comprehensive picture of oxygen profiles in low-activity sediments, different methods were used for their investigation at different spatial scales. Oxygen profiles in the top few centimeters of the sediments were measured with microelectrodes profiling top down, both in situ with a benthic lander and ex situ in recovered cores. To investigate deeper sediment layers, oxygen concentrations were measured ex situ with needle-shaped optodes through drilled holes in piston core liners.

\subsection{In situ measurements}

A free falling, programmable benthic lander was used to measure oxygen profiles in the top centimeters in situ with high resolution (Archer et al., 1989; Wenzhöfer and Glud, 2002). The lander was equipped with a microelectrode profiler enabling profiling in $100 \mu \mathrm{m}$ steps down to $5 \mathrm{~cm}$. Onboard sensor calibration prior to the deployment was performed with air-saturated and anoxic seawater at in situ temperature. The obtained profiles were used to calculate diffusive fluxes into the sediment, using Fick's first law of diffusion (Berner, 1980). Since the diffusive boundary layer (DBL) could not accurately be determined from the profiles, the diffusive flux (DOU) was calculated from gradients just below the sediment surface:

$\mathrm{DOU}=-\left.\phi D_{s} \frac{\partial C}{\partial z}\right|_{z=0}=-\left.\frac{D_{0}}{F} \frac{\partial C}{\partial z}\right|_{z=0}$

where $\Phi$ represents the porosity and $D s$ is the sediment diffusion coefficient (corrected for tortuosity). The molecular diffusion coefficient of oxygen in free solution $D_{0}=1.13 \mathrm{e}^{-9} \mathrm{~m}^{2} \mathrm{~s}^{-1}$ was taken from (Schulz and Zabel, 2000) and corrected for in situ salinity and temperature ( $\mathrm{Li}$ and Gregory, 1974). We did not determine the sediment porosity directly. Instead, we measured the formation factor $F$ as the ratio of the electric resistivity of the bulk sediment to the resistivity of the unrestricted porewater (Fig. 2). Conductivity was determined with a Brinkman/Metrohm Conductometer every $5 \mathrm{~cm}$ in the center of split piston cores. The probe consisted of two $2 \mathrm{~mm} \varnothing$ platinum electrodes spaced $1 \mathrm{~cm}$ apart. All calculations were done using an average sediment formation factor $F$ of 1.69. In subsequent equations, we express $D_{0} / F$ as $\Phi D_{s}$ for consistency with the literature. The lander was deployed at Stations 2, 5, 7 and 10. However, due to technical problems, in situ microprofiles could be obtained only at Station 10.

\subsection{Ex situ measurements on multi-cores}

To study the top sediment layer in more detail, sediment was recovered using a Multiple Corer (Barnett et al., 1984). These cores appeared undisturbed with intact microstructure at the sediment surface. Immediately after recovery, the sealed tubes were stored at $4^{\circ} \mathrm{C}$. Small rotating magnets ensured well-mixed overlying waters and prevented a too large DBL to develop (Glud et al., 1994; Rasmussen, 1992). Due to technical limitations, oxygen profiles were measured only 


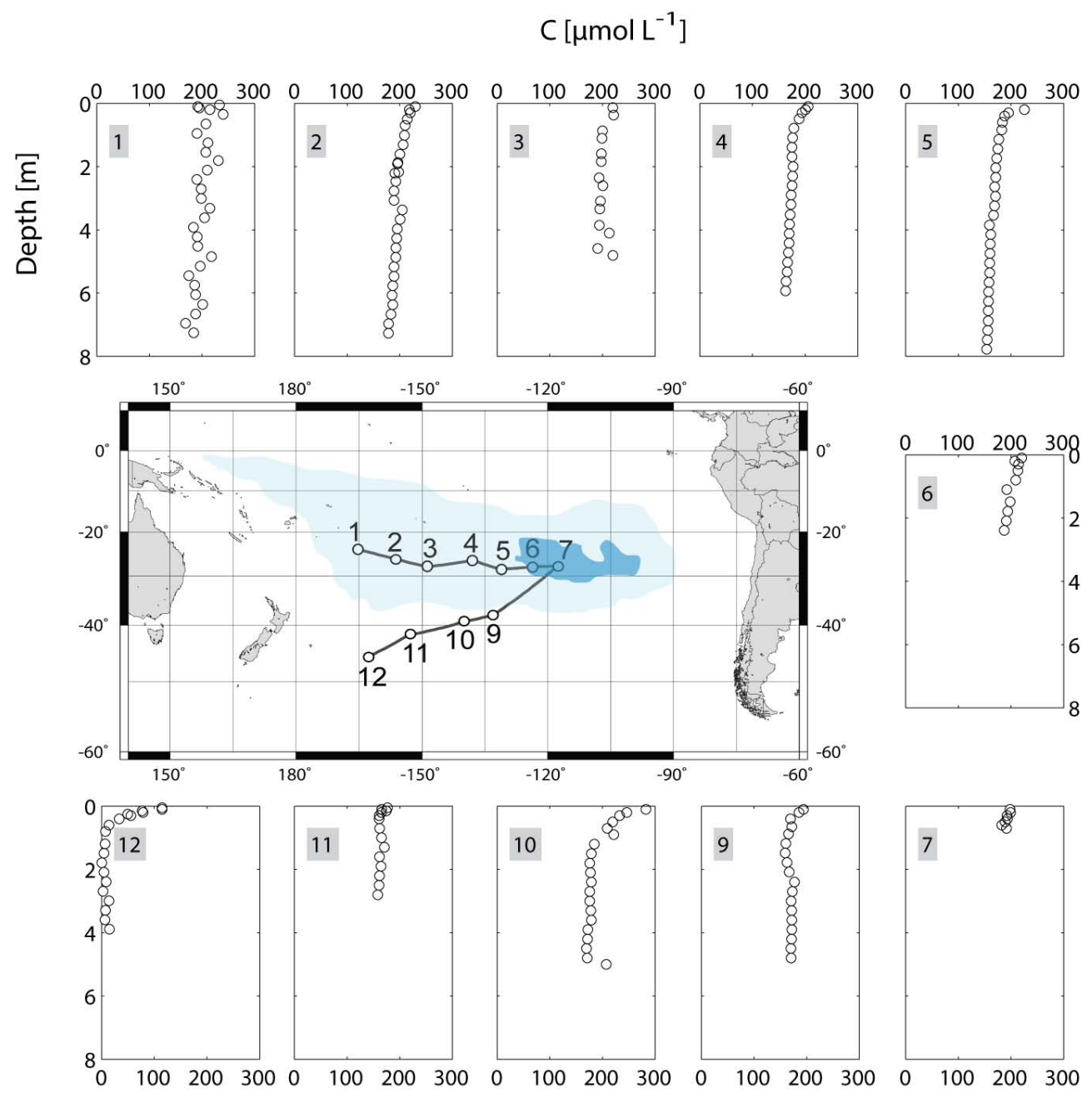

Fig. 1. Sampling stations in the South Pacific (middle) and deep oxygen profiles at the respective positions. The shaded areas depict surface chlorophyll concentrations below 0.1 (light blue) and 0.03 (dark blue) $\mathrm{mg} / \mathrm{m}^{3}$, respectively. The chlorophyll concentration of the remaining sampling area was between 0.1 and $0.25 \mathrm{mg} / \mathrm{m}^{3}$ (averaged SeaWiFS remote sensing data).

at 4 out of the 11 stations with Clark-Type microelectrodes (Revsbech, 1989), a custom-made picoamperemeter, an A/D converter (DAQPad-6020E, National Instruments) and a motorized stage (VT-80, Micos GmbH, Germany). The calculation of DOUs was carried out as described in Sect. 2.2. It is known that ex situ measurements of oxygen profiles are biased by core recovery artifacts, tending to underestimate the oxygen penetration depth and to overestimate the calculated benthic flux (Glud et al., 1994). Sediment decompression and warming as well as enhanced availability of labile organic matter are possible explanations. These findings result from investigations in highly productive areas with high gradients and low oxygen penetration depths. Since our measurements were performed in low-productivity regions with deep oxygen penetration and low microbial activities, only little differences between in situ and ex situ results are to be expected.

\subsection{Ex situ measurements on piston cores}

We compared measurements with clark-type microelectrodes and needle optodes on both-, piston cores and trigger cores (which operate like gravity cores) of Stations 1 and 2 and found no significant difference in the oxygen profiles (data not shown). However, the signals of the optodes were found to be more stable and precise. Since optodes are also mechanically more robust, they were used for all subsequent measurements. Oxygen concentrations in one piston core were measured per station. The optode itself consisted of a fiber optic cable $(125 \mu \mathrm{m} \varnothing)$, glued into a stainless steel capillary that was reinforced by another stainless steel tube into which the capillary was fit (Klimant et al., 1995; Wenzhöfer et al., 2001). The fiber tip was polished using lapping film with decreasing grain size, down to $0.5 \mu \mathrm{m}$ (3M Inc.). The sensing dye consisted of $2 \%$ platinum(II) mesotetra (pentafluorophenyl) porphyrin (Frontier Scientific, Inc.) in 


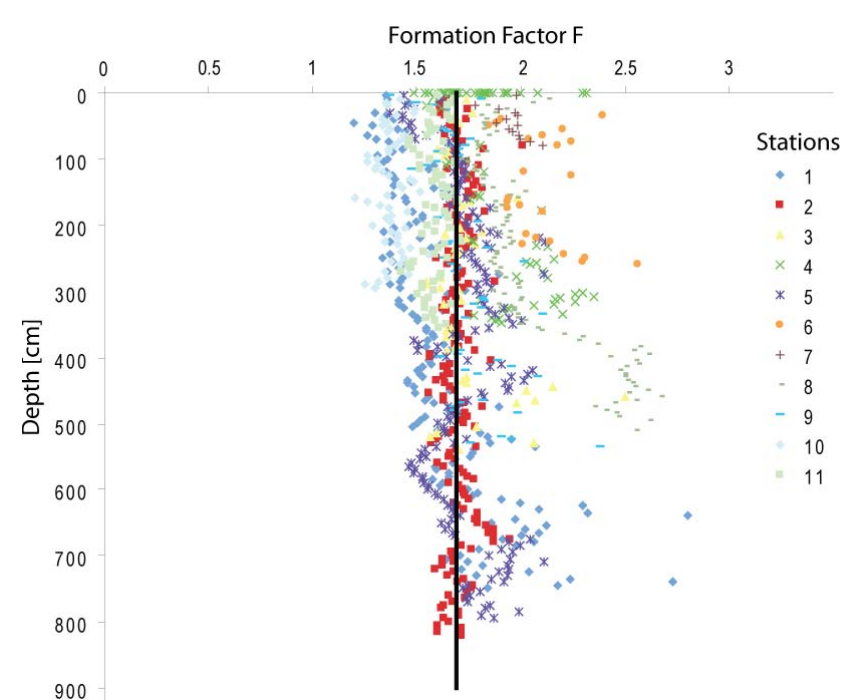

Fig. 2. Sediment formation factors as calculated from conductivity measurements on cores of all stations. The black line represents the average value of 1.69 .

a polystyrene matrix. To coat the fiber tip, the mixture was dissolved in chloroform and applied under a microscope using a micromanipulator. Optode readout was done using a MICROX TX3 (PreSens Precision Sensing GmbH) optode meter. A two-point calibration was done using anoxic and air-saturated seawater at room temperature about every $2 \mathrm{~h}$. Conversion of the measured fluorescence lifetime of the optode to oxygen values was done internally by the instrument, using a modified Stern-Vollmer equation.

After recovery, the piston cores were cut into sections of $150 \mathrm{~cm}$ and the ends were sealed with PVC caps and adhesive tape. The cores were allowed to thermally equilibrate for at least $24 \mathrm{~h}$ in the lab at $20^{\circ} \mathrm{C}$ before the measurements started. The raised temperature decreases the solubility of oxygen within the porewater of the sediment. If supersaturation was reached, a change in oxygen concentration would have been the result. However, the oxygen solubility at $20^{\circ} \mathrm{C}$ and salinity of 35 is $231 \mu \mathrm{mol} \mathrm{L}^{-1}$. This is below the bottom water concentration at all sites. Therefore, oversaturation could not occur. Since the volumetric $\mathrm{O}_{2}$ consumption rates in the deeper layers were very low, we assume that small variation in this rate due to warming will not affect our measurements on the time scales involved. Immediately prior to each measurement, two $6 \mathrm{~mm} \varnothing$ holes were drilled through the core liner in close vicinity to each other using a spiral drill with a stop unit to prevent drill penetration into the sediment. The self-made fiber sensor was inserted through one of the holes into the center of the core and a temperature probe for thermal compensation was inserted through the second hole. Over the first $50 \mathrm{~cm}$ of the piston core, measurements were done in $10 \mathrm{~cm}$ intervals, while the remaining core was measured in $20-30 \mathrm{~cm}$ intervals. After insertion of the optode into the center of the core, the sensor was allowed to equilibrate for about $15 \mathrm{~min}$, before the optode readout was averaged over $5 \mathrm{~min}$. A randomized order of measurements along the core prevented measurement drift artifacts. To ensure that the center of the core was unaffected by ambient air that diffused into the core after recovery, radial microsensor profiles with a clark-type microsensor were done on a core that was left in the lab for $32 \mathrm{~h}$. In a distance of about $2 \mathrm{~cm}$ from the core liner, the oxygen profile leveled-off, showing that the center of the $10 \mathrm{~cm} \varnothing$ core was undisturbed (data not shown).

\subsection{Modeling}

Our model analysis of the oxygen profile is based upon steady-state mass balance of oxygen in the pore water. We used different parameterizations of a 1-D reaction-diffusion model to analyze different aspects of the data. Since bioturbation and sedimentation can be neglected in the SPG, the 1-D-model can be formulated as

$\phi D_{s} \frac{\partial^{2} C}{\partial z^{2}}-R_{\text {surf }}-R_{\text {deep }}=0$

where $\Phi$ is the porosity, $D_{s}$ the sediment diffusion coefficient ( $\Phi D_{s}$ was measured as $D_{0} / F$, s. Sect. 2.2), $C$ the oxygen concentration, $z$ is the depth within the sediment and $R_{\text {surf }}$ and $R_{\text {deep }}$ are terms describing the $\mathrm{O}_{2}$ consumption rate close to the sediment surface (labile organic carbon) and deep within the sediment (refractory organic carbon). There was no clear trend in the formation factor with depth and the scatter in the measurements was relatively high (Fig. 2). Therefore, we used an average (constant) formation factor of 1.69 for all calculations. Since it is likely that the first meter of the piston cores was disturbed during coring (Buckley et al., 1994; Skinner and Mccave, 2003), we excluded these data points from our analysis of the deep oxygen profiles.

In order to obtain upper and lower bounds for rates deep within the sediment at each site, we varied $R_{\text {deep }}$ and the oxygen flux $F_{d}$ at the lower boundary of the domain $z_{\max }$, which was set to the depth of the deepest data point. The use of a mean value of the topmost three data points for $C_{0}$ was chosen to account for scatter in the data. We assumed that $R_{\text {deep }}$ remained constant with depth and since the surface sediment layer was not included in this modeling step, $R_{\text {surf }}$ was set to zero. We used the symbolic math software Maple (Maplesoft, Inc.) to obtain an analytical solution for the oxygen concentration $C$ at depth $z$ (in meters below $C_{0}$ ) with the given boundary conditions:

$C(z)=\frac{1}{2} \frac{R_{\text {deep }}}{\phi D_{s}} z^{2}+\frac{z}{\phi D_{s}}\left(F_{d}-R_{\text {deep }} z_{\text {max }}\right)+C_{0}$

The goodness of fit was evaluated by calculating generalized $\mathrm{R}^{2}$ values for all tested combinations of $F_{d}$ and $R_{\text {deep }}$ as the sum of squares of the distances of the data points to the fitted model at the respective depths, normalized to the squared distances of the points to the mean of all values $\left(R^{2}=1-\mathrm{SSR} / \mathrm{SST}\right.$; Schabenberger and Pierce, 2001). 
To incorporate the high-resolution microprofiles in the model (Eq. 2), $R_{\text {deep }}$ was set to constant values, found in the model calibration for the deep sediment described above. A depth-dependent $\mathrm{O}_{2}$ consumption rate was assumed to account for the much higher respiration in the top layer, decreasing exponentially with depth:

$R_{\text {surf }}(z)=R_{\max } e^{-\alpha z}$

The bottom water concentration $C_{0}$ was used as top boundary condition whereas a fixed flux $\left(F_{d}\right)$ to the basalt was chosen as bottom boundary condition. As analytical solution of Eqs. (2) and (4) with these boundary conditions, we obtained:

$$
\begin{aligned}
C(z)= & \frac{1}{\phi D_{s}}\left(\frac{R_{\max } e^{-\alpha z}}{\alpha^{2}}+\frac{R_{\mathrm{deep}} z^{2}}{2}+\right. \\
& \left.z\left(\frac{R_{\max } e^{-\alpha z_{\max }}}{\alpha}-R_{\mathrm{deep}} z_{\max }+F_{d}\right)-\frac{R_{\max }}{\alpha^{2}}\right)+C_{0}
\end{aligned}
$$

A simultaneous variation of $R_{\max }$ and $\alpha$ was performed to fit the model to the complete dataset, including microsensor and piston core measurements. The flux to the basalt was set to zero for this study $\left(F_{d}=0\right)$. For a more intuitive interpretation of the fit parameter $\alpha$, the depth $z_{\text {half }}$ at which the rate drops to half the surface rate $R_{\max }$ can be calculated from $\alpha$ as:

$z_{\text {half }}=-\frac{\ln (0.5)}{\alpha}$

Since the system is not electron-acceptor limited, this can be regarded as the depth where half of the reactive organic matter is used up.

To compare the integrated $\mathrm{O}_{2}$ consumption rates in the surface with the integrated rates deeper in the sediments, the flux to the surface layer was calculated as

$F_{\text {surf }}=\int_{z=0}^{\infty} R_{\text {surf }}(z) d z$ with Eq. (4), this simplifies to $F_{\text {surf }}=\frac{R_{\max }}{\alpha}$

and the integrated deep uptake as

$F_{\text {deep }}=R_{\text {deep }} z_{s}$

with $z_{s}$ being the thickness of the sediment at the respective station.

\subsection{Calculation of carbon input}

Several empirical models have been proposed for the calculation of the carbon flux to oceanic sediments from primary production in surface waters (e.g. Berger et al., 1987; Betzer et al., 1984; Pace et al., 1987; Suess, 1980). Specific models for oligotrophic regions, however, do not exist. The model composed by Antia et al. (2001) was used in this study $\left(J_{\text {POC_A }}=0.1 \mathrm{PP}^{1.77} z^{-0.68}\right)$ since it represents an average of the cited models, where PP is the surface water primary production in $\mathrm{gC} \mathrm{m}^{-2} \mathrm{yr}^{-1}$ and $z$ the water depth in meters. Primary production values were estimated from SeaWiFs remote sensing data, converted into integrated annual primary productivity by the IMCS Ocean Primary Productivity Team (Rutgers, State University of New Jersey) using the algorithms from Behrenfeld and Falkowski (1997). To convert the measured oxygen fluxes into fluxes of labile organic carbon $\left(J_{\mathrm{POC} \_} \mathrm{R}\right)$ we used a respiratory quotient $\left(\mathrm{O}_{2}: \mathrm{C}\right)$ of 1.3 .

\section{Results and discussion}

Biogeochemical processes in sediments can be divided into transport phenomena and reaction processes. In general, important vertical transport processes in marine sediments are bioturbation/bioirrigation, advection and molecular diffusion (Berg et al., 2001). Since we found very few traces of macrobenthos in the SPG, bioturbation and bioirrigation are likely to be negligible for solute transport; the low permeability of clay sediments (Spinelli et al., 2004) found at all stations also excludes any appreciable advection. Therefore, molecular diffusion is the dominant transport process in these oligotrophic sediments, and together with biogeochemical reactions (e.g. respiration), controls the penetration of oxygen into the sediment.

\subsection{Benthic carbon fluxes}

Microsensor oxygen profiles of the uppermost sediment layer were measured ex situ in recovered sediment cores at Stations 4-7 and in situ at Station 10 (Fig. 7, right panels). A general trend of decreasing oxygen fluxes toward the center of the gyre was observed (Table 1), varying between $0.12 \mathrm{mmol} \mathrm{m}^{2} \mathrm{~d}^{-1}$ (Station 6) and $1.32 \mathrm{mmol} \mathrm{m}^{2} \mathrm{~d}^{-1}$ (Station 4). However, the value at Station 4 appears exceptionally high, especially compared to Station 10. Here, farthest away from the center of the gyre and with the highest surface productivity, higher rates than closer to the center would have been expected. It has to be noted, that Station 10 represents the only in situ measurement and ex situ measurements tend to overestimate DOU (e.g. Glud, 2008). However, locally enhanced consumption rates can also not be excluded.

The measured oxygen fluxes are slightly lower compared to previously reported fluxes from oligotrophic sediments in the Atlantic $\left(>0.3 \mathrm{mmol} \mathrm{m}^{2} \mathrm{~d}^{-1}\right.$; Wenzhöfer and Glud, 2002; Wenzhöfer et al., 2001), however, an older study by Smith (1978) reported oxygen fluxes in the NW Atlantic as low as $0.02 \mathrm{mmol} \mathrm{m}^{2} \mathrm{~d}^{-1}$. The fluxes reported here are higher than some fluxes measured in the central equatorial Pacific (0.09-0.68 $\mathrm{mmol} \mathrm{m}^{2} \mathrm{~d}^{-1}$; Hammond et al., 1996, and 0.013-0.22 mmol m $\mathrm{m}^{-1}$; Murray and Grundmanis, 1980) even though there is a lower primary production in the surface-water of the SPG. However, the coarse sampling resolution of several centimeters by Murray and Grundmanis (1980) and Hammond et al. (1996) very likely 
Table 1. Sampling positions, waterdepth [m], sediment thickness [m], diffusive oxygen uptake (DOU) and fluxes of particulate organic matter as calculated from primary production $\left(J_{\text {POC_A }}\right)$ or using the oxygen fluxes $\left(J_{\text {POC_R }}\right)$. Units: DOU: $\mathrm{mmol} \mathrm{m}^{-2} \mathrm{~d}^{-1} \mathrm{PP}, J_{\mathrm{POC} \_\mathrm{A}}$, $J_{\text {POC_R }}: \mathrm{gC} \mathrm{m}^{-2} \mathrm{yr}^{-1}$. Sediment thicknesses after D'Hondt et al. (2009).

\begin{tabular}{llllclcccc}
\hline Stat. & Lat. & Lon. & W. depth & Sed. Thick. & bottom W. O2 & DOU & $J_{\text {POC_R }}$ & PP & $J_{\text {POC_A }}$ \\
\hline 1 & $23^{\circ} 51^{\prime}$ & $165^{\circ} 39^{\prime}$ & 5697 & 71 & 203 & - & - & 77 & 0.61 \\
2 & $26^{\circ} 03^{\prime}$ & $156^{\circ} 54^{\prime}$ & 5127 & 17 & 228 & - & - & 83 & 0.75 \\
3 & $27^{\circ} 57^{\prime}$ & $148^{\circ} 35^{\prime}$ & 4852 & 5.5 & 218 & - & - & 86 & 0.83 \\
4 & $26^{\circ} 29^{\prime}$ & $137^{\circ} 56^{\prime}$ & 4285 & 9.4 & 217 & 1.32 & 4.46 & 72 & 0.66 \\
5 & $28^{\circ} 27^{\prime}$ & $131^{\circ} 23^{\prime}$ & 4221 & 16.5 & 220 & 0.45 & 1.51 & 77 & 0.75 \\
6 & $27^{\circ} 55^{\prime}$ & $123^{\circ} 10^{\prime}$ & 3738 & 15 & 221 & 0.12 & 0.40 & 70 & 0.69 \\
7 & $27^{\circ} 45^{\prime}$ & $117^{\circ} 37^{\prime}$ & 3688 & 1.5 & 202 & 0.26 & 0.88 & 66 & 0.69 \\
9 & $38^{\circ} 04^{\prime}$ & $133^{\circ} 06^{\prime}$ & 4925 & 19.8 & 205 & - & - & 118 & 1.90 \\
10 & $39^{\circ} 19^{\prime}$ & $139^{\circ} 48^{\prime}$ & 5283 & 21.4 & 227 & 0.23 & 0.79 & 113 & 1.60 \\
11 & $41^{\circ} 51^{\prime}$ & $153^{\circ} 06^{\prime}$ & 5076 & 67 & 213 & - & - & 130 & 1.90 \\
12 & $45^{\circ} 58^{\prime}$ & $163^{\circ} 11^{\prime}$ & 5306 & 130 & 205 & - & - & 157 & 2.49 \\
\hline
\end{tabular}

underestimates the oxygen consumption at the sedimentwater interface. Reimers et al. (1984) report microelectrode measurements in the central Pacific with values between 0.2 and $0.8 \mathrm{mmol} \mathrm{m}^{2} \mathrm{~d}^{-1}$, supporting this assumption.

Since the vast majority of organic matter that reaches the seafloor is ultimately oxidized, oxygen fluxes can be used to calculate organic carbon fluxes (Jahnke, 1996). Converting our measured oxygen fluxes into carbon equivalents, assuming a respiration coefficient of 1.3 resulted in carbon fluxes $\left(J_{\text {POC_R }}\right.$ ) between 0.40 and $4.46 \mathrm{gC} \mathrm{m}^{-2} \mathrm{yr}^{-1}$ with a mean of $1.61 \mathrm{gC} \mathrm{m}^{-2} \mathrm{yr}^{-1}$ (Table 1). These carbon fluxes are in the same order of magnitude as fluxes reported for the deep North Pacific (Murray and Kuivila, 1990). These carbon fluxes $\left(J_{\mathrm{POC} \_}\right)$generally confirm the extrapolated estimates of Jahnke (1996) for the SPG which were based on a rather simple extrapolation procedure. The decrease of fluxes towards the center of the gyre parallels a decrease in surface water primary production, indicating that the benthic mineralization is primarily fueled by the export of organic matter from surface waters.

Using primary production estimates from ocean color data (Behrenfeld and Falkowski, 1997) and an empirical model for carbon export to deep waters (Antia et al., 2001) permits an alternative estimation of the particulate organic carbon $\left(J_{\text {POC_A }}\right)$ fluxes to the sediment. Given the high discrepancies generally found between POC fluxes, calculated from ocean color data and sediment trap measurements (Gehlen et al., 2006), the fluxes from remote-sensing PP generally agree with the fluxes derived from our oxygen profiles $\left(J_{\text {POC } \_R}\right)$, at Stations 4,5 and $7, J_{\mathrm{POC} \_\mathrm{R}}$ exceeds $J_{\mathrm{POC} \_\mathrm{A}}$ by $21-85 \%$, while at Stations 6 and 10, JPOC_A is $74 \%$ and $103 \%$ larger, respectively. Generally, $J_{\mathrm{POC} \_\mathrm{A}}$ shows a lower variability between the stations on the northern transect than $J_{\mathrm{POC} \_}$. Differences between $J_{\mathrm{POC} \_\mathrm{R}}$ and $J_{\mathrm{POC} \_\mathrm{A}}$ were not correlated to surface chlorophyll concentrations or sedimentation rates. One cause for the remaining differences may be the assumption that the formation factor remains constant with depth, and hence one ignores the porosity gradient in the surface layer. Another, and maybe more likely, explanation for the discrepancy may be that the empirical algorithms used to correlate chlorophyll- $\alpha$ content with ocean color are based mostly on data points in the Northern Hemisphere with few points from oligotrophic gyres (Claustre and Maritorena, 2003). Although quantification of primary production by remote sensing has improved, oligotrophic regions are still poorly represented and empirical models for carbon export fluxes are poorly constrained (e.g. Gehlen et al., 2006). The presence of a very large pool of dissolved organic matter in the SPG (Raimbault et al., 2008) can furthermore skew the results and lead to overestimation of primary production estimates derived from remote sensing (Claustre and Maritorena, 2003). Additionally, Dandonneau et al. (2003) argue, that floating particles can cause significant artifacts in chlorophyll sensing in oligotrophic waters. All these factors could lead to increasing overestimations of $J_{\mathrm{POC} \_\mathrm{A}}$ towards the center of the gyre. While the limited number of sampling stations in our study and uncertainties about the porosity gradient in the first millimeters of the sediment does not allow a final conclusion about the magnitude of cross-gyre differences in carbon mineralization, the overall average magnitude of carbon mineralization at the seafloor for this region has, for the first time, been experimentally constrained.

\subsection{Coupling surface and deep respiration}

The low sedimentation rates in the SPG prevents labile organic carbon from reaching deeper sediment layers, and thus respiratory activity strongly drops with depth, and the gradient in the oxygen concentration rapidly decreases as can be seen from the microprofiles (Fig. 7, right panels). The measured $\mathrm{O}_{2}$ fluxes at the sediment-water interface are not exceptionally low compared to other oligotrophic open-ocean 
sites (Hammond et al., 1996; Murray and Grundmanis, 1980; Suess, 1980; Wenzhöfer and Glud, 2002). Nevertheless, because of the inert nature of the deeper sediment, any oxygen that escapes consumption in the surface layers is free to diffuse downwards and oxygenate deep layers. All piston cores within the central gyre were oxygenated over their entire length (up to $8 \mathrm{~m}$, Fig. 1). The only station where oxygen did not penetrate to the base of the core is Station 12, farthest away from the center of the gyre, where oxygen penetrated about $1 \mathrm{~m}$ into the sediment. Generally, the piston cores showed a drop in oxygen concentration within the first meter from bottom water concentration $\left(220 \mu \mathrm{mol} \mathrm{L}^{-1}\right)$ to $170-180 \mu \mathrm{mol} \mathrm{L}^{-1}$. However, in the microsensor profiles, both-, ex situ and in situ, this same initial drop in concentration was already observed within the first few centimeters. The considerably greater interval over which this decrease occurred in the piston cores $(\sim 1 \mathrm{~m})$ most likely resulted from the coring process, mixing the top section of the cores (Buckley et al., 1994; Skinner and McCave, 2003).

The downward oxygen flux within the deep piston cores was constrained in two ways. First, we simply fitted a linear trend to the oxygen profile below 1 mbsf to obtain an estimate of the downward oxygen flux $F_{d}\left(R_{\text {deep }}=0\right)$. A decrease of $F_{d}$ towards the center of the gyre is suggested (Fig. 6), yet it is statistically not significant. In a second step, we fitted a 1-D diffusion-reaction model (Eq. 3) to the deep profiles below $1 \mathrm{mbsf}$ (Fig. 3) while varying the respiration rate $\left(R_{\text {deep }}\right)$ and the downward flux $\left(F_{d}\right)$ at the lower boundary provides lower and upper constraints on the respiration rate. Figure 4 shows combinations of the parameter $R_{\text {deep }}$ and $F_{d}$ that lead to the fits shown in Fig. 3. Reasonably good fits could be obtained for $\mathrm{O}_{2}$ consumption rates between zero and $\sim 30 \mu \mathrm{mol} \mathrm{m}^{-3} \mathrm{yr}^{-1}$. Downward fluxes are likely to be below $0.3 \mu \mathrm{mol} \mathrm{m}^{-2} \mathrm{~d}^{-1}$ but above $0.05 \mu \mathrm{mol} \mathrm{m}^{-2} \mathrm{~d}^{-1}$ except for Stations 6 and 9, where lower fluxes appear to be possible (Fig. 4). Note however that these fluxes and consumption rates are very small and, as shown in Fig. 4, the downward flux $F_{d}$ correlates strongly with the oxygen consumption rate $R_{\text {deep }}$, which makes that these two parameters are not well constrained. Additionally, different scatter in the data lead to values of $R^{2}$ of the best fitting model between 0.23 at Station 9 and 0.91 at Station 5 .

Extrapolation of 10 exemplary profiles obtained from the range of well fitting parameters down to the basalt for each site, suggests the presence of oxygen within the entire sediment column (Fig. 5). Exceptions are Stations 1 and 11, where oxygen might have reached zero within the sediment. The complete oxygenation of the sediment column excludes all other electron acceptors from use and the low overall respiration rates deep in the sediment effectively stretch the zone over which the aerobic degradation of organic matter occurs to several meters.

The whole oxygen profile, including surface and deeper layers was modeled for all stations, where surface microsensor profiles were available (Stations 4-7 and 10), assuming
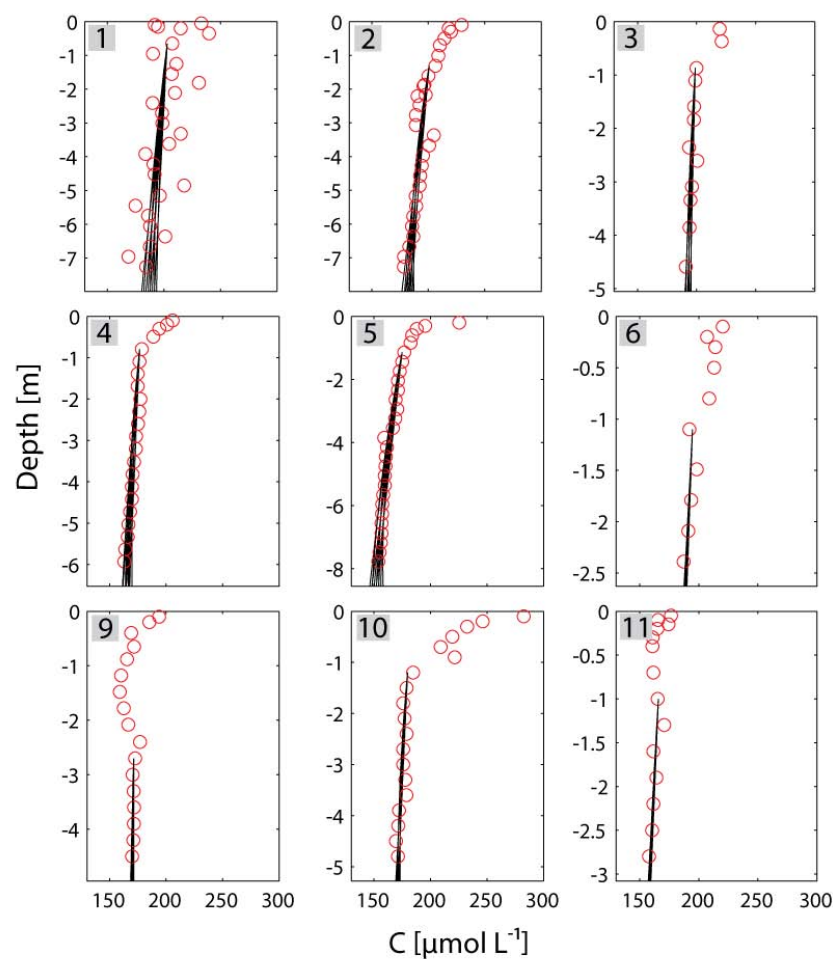

Fig. 3. Best fitting model runs for 9 different stations (black lines) as a result of a variation of the constant respiration rate $R_{\text {deep }}$ and the flux at the lower boundary $F_{d}$. Please note the different scales on the depth axis.

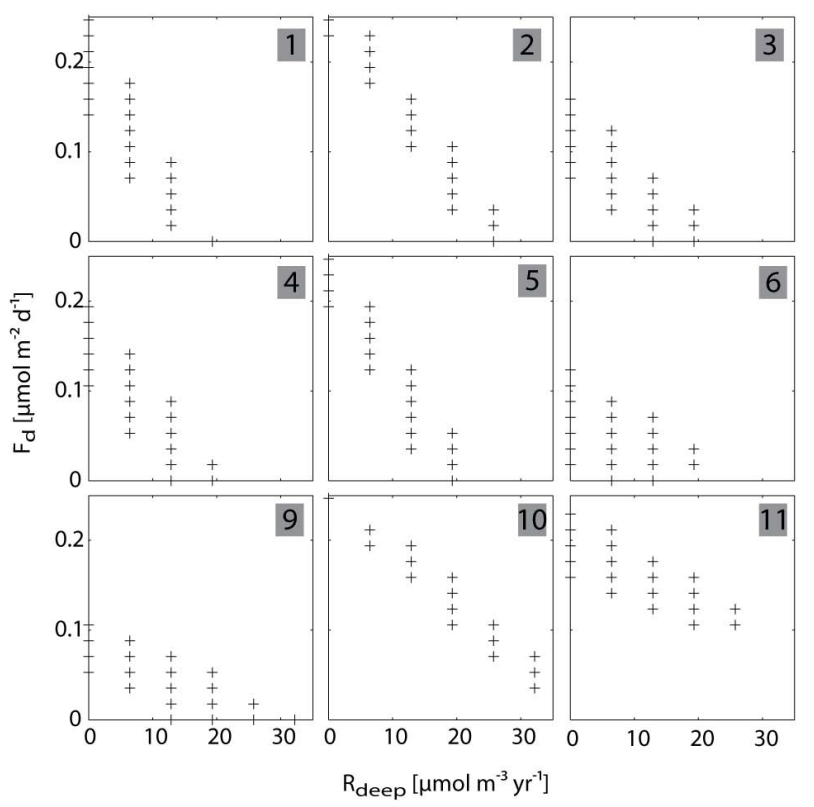

Fig. 4. Parameter combinations for the best fitting profiles of Figs. 3 and 5. 

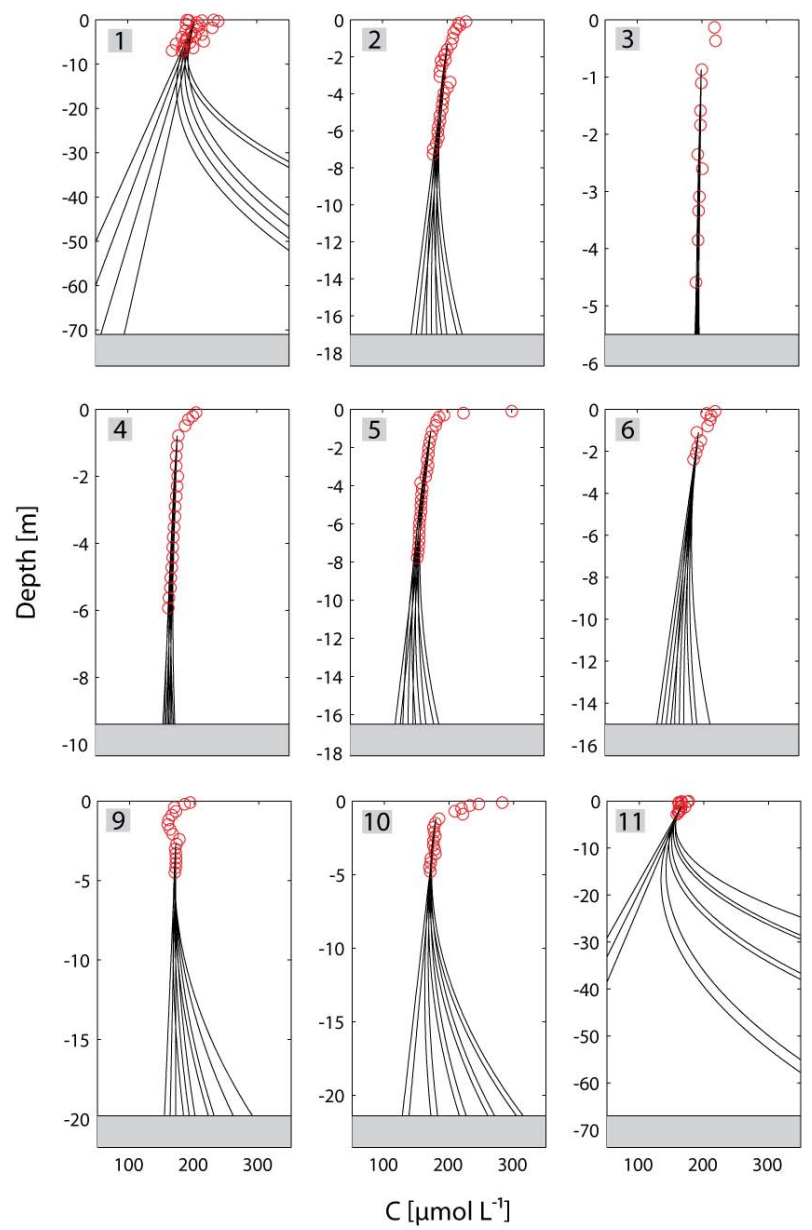

Fig. 5. Extrapolated profiles of oxygen concentration of 9 different stations down to the basalt (grey bar). Circles indicate measured oxygen concentrations; solid lines depict the extrapolations for different parameter constellations for the deep respiration rate and the flux (for further information see text).

exponentially decreasing rates in the top centimeters plus a constant term accounting for the deep aerobic respiration (Fig. 7). A similar approach to model sediment $\mathrm{O}_{2}$ profiles was taken by Hammond et al. (1996) for central Pacific sediments. However, they assumed a sum of two exponentially decreasing respiration terms and applied the model to coarse resolution porewater measurements of the top centimeters only.

We found the model to be in excellent accord with the data $\left(R^{2}>0.94\right)$ for all 5 stations. The exponential term can be explained by a pool of reactive organic matter which is being exploited by the microbial community, following first order reaction kinetics. Half of the reactive organic matter was consumed in depths $\left(z_{\text {half }}\right)$, varying between $1.3 \mathrm{~mm}$ (Station 4) and $6 \mathrm{~mm}$ (Station 10) (Fig. 7). Given that the sedimentation rate is in the order of 0.1 to $1 \mathrm{~mm} \mathrm{kyr}^{-1}$ (D'Hondt et al., 2009), a low rate constant for organic carbon oxidation can be expected and intraanual variations in sediment oxygen uptake are unlikely (Sayles et al., 1994).

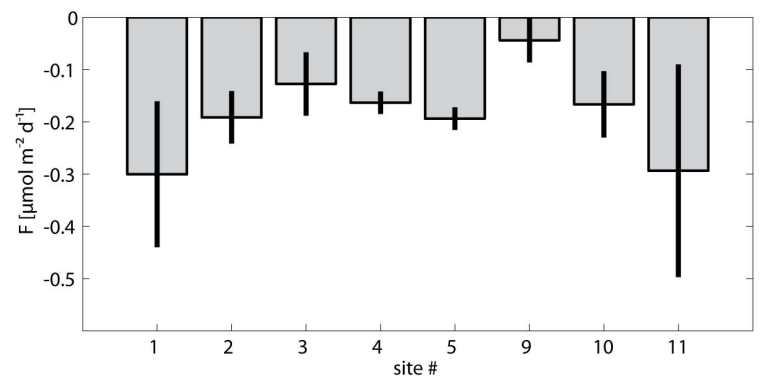

Fig. 6. Deep fluxes calculated from linear fits of the measured oxygen profiles on piston cores. Error bars represent $90 \%$ confidence intervals. Station 6 was omitted due to the low number of data points below $1 \mathrm{~m}$.

By integrating the exponentially decreasing respiration rate $R_{\text {surf }}(z)$ over the whole sediment thickness using the best fitting parameter combinations, the integrated $\mathrm{O}_{2}$ consumption in the upper sediment layer is calculated $\left(F_{\text {surf }}\right.$, Eq. 7$)$. It is 3-4 orders of magnitude higher compared the deeper sediment as calculated by the integrated rate $R_{\text {deep }}\left(F_{\text {deep }}\right.$, Eq. 8$)$ (Table 2). Given the small values of $z_{\text {half }}$ (Table 2), more than 99.9\% of the total oxygen that enters the sediment is consumed in the top few centimeters of the sediment and only a very small proportion is taken up by the deep subsurface or enters the basaltic basement. Since the DOU values (Table 1) were obtained by linear interpolation of the oxygen profiles within the top millimeter below seafloor, small differences to the summarized surface- and deep fluxes as obtained by the model were found.

The deep $\mathrm{O}_{2}$ consumption can be fueled by slow degradation of highly refractory organic matter, up to millions of years old. The small decline of total organic carbon with depth in the deeper layers as reported by D'Hondt et al. (2009) would agree well with this. In this case, the low respiration term would not be constant but declining with such a low decrease with depth that it is not significantly different from a constant term. Another explanation for the relatively constant deep respiration would be the radiolysis of water due to radioactive decays in sediment grains (Blair et al., 2007; D'Hondt et al., 2009; Jørgensen and D'Hondt, 2006). This process, reported for continental rock by Lin et al. (2005), would split water in hydrogen and hydroxyl radicals. The hydrogen could act as electron donor while the hydroxyl radicals could further react to molecular oxygen. If this reaction is stoichiometric, the whole process is completely cryptic and is not reflected in the oxygen profiles at all, since the produced hydrogen and oxygen could be recombined microbially to water. If the hydroxyl radical, however, does not completely form molecular oxygen but further reacts with organic material or mineral surfaces, the additionally stimulated respiration could account for the constant respiration rate over depth that we observed. The bioavailability of refractory organic matter can be enhanced by reaction 

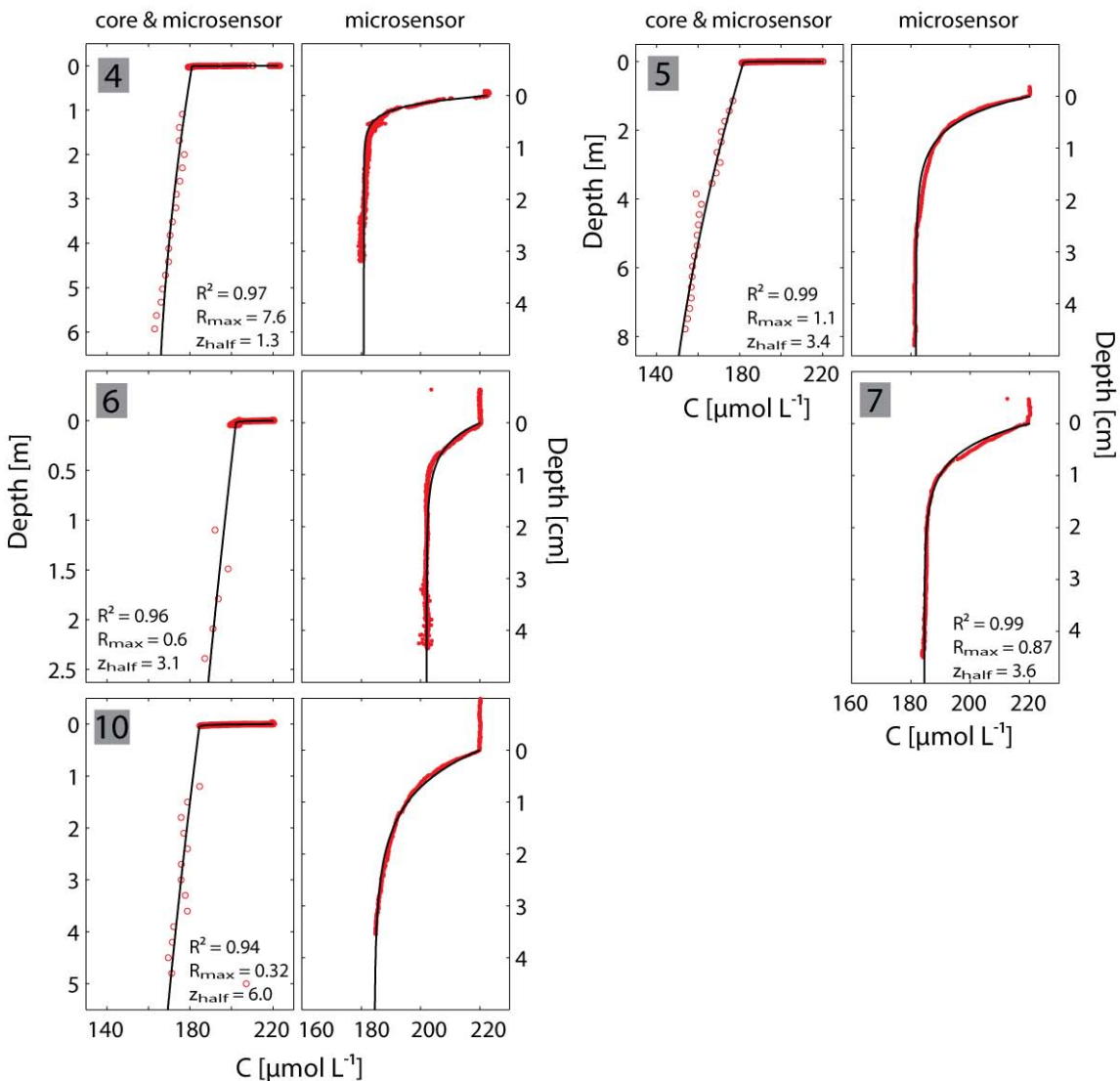

Fig. 7. Composed profiles of Stations 4-7 and 10, using data from piston core measurements and microprofiler (red symbols) and fitted model with exponentially decreasing respiration rates with depths for the upper sediment layer plus constant offset, accounting for deep respiration (solid line). The left panels show the composed profiles, whereas the right panels represent a magnification of the top $5 \mathrm{~cm}$, showing microsensor data and model result only. For Station 7, no deep measurements (below $1 \mathrm{~m}$ ) were available. Units: $R_{\max }\left[\mathrm{nmol} \mathrm{cm}^{-3} \mathrm{~s}^{-1}\right.$; $z_{\text {half }}[\mathrm{mm}]$.

Table 2. Best fitting parameters of the combined surface and deep oxygen uptake model (Fig. 7, Eq. 5). The values for $F_{\text {surf }}$ represent the total flux of oxygen due to the exponential (surface) term while $F_{\text {deep }}$ are the respective fluxes due to the constant (deep) term (s. text for details).

\begin{tabular}{llllll}
\hline Stat. & $\begin{array}{l}R_{\text {deep }} \\
{\left[\mu \mathrm{mol} \mathrm{m}^{-3} \mathrm{yr}^{-1}\right]}\end{array}$ & $\begin{array}{l}R_{\max } \\
{\left[\mu \mathrm{mol} \mathrm{m}^{-3} \mathrm{~s}^{-1}\right]}\end{array}$ & $\begin{array}{l}z_{\text {half }} \\
{[\mathrm{mm}]}\end{array}$ & $\begin{array}{l}F_{\text {surf }} \\
{\left[\mathrm{mmol} \mathrm{m}^{-2} \mathrm{~d}^{-1}\right]}\end{array}$ & $\begin{array}{l}F_{\text {deep }} \\
{\left[\mu \mathrm{mol} \mathrm{m}^{-2} \mathrm{~d}^{-1}\right]}\end{array}$ \\
\hline 4 & 7.88 & 7.59 & 1.3 & 1.26 & 0.20 \\
5 & 6.31 & 1.06 & 3.4 & 0.45 & 0.29 \\
6 & 7.88 & 0.59 & 3.1 & 0.23 & 0.32 \\
7 & 7.88 & 0.88 & 3.6 & 0.39 & 0.03 \\
10 & 3.15 & 0.32 & 5.9 & 0.25 & 0.18 \\
\hline
\end{tabular}

\subsection{Basement fluxes}

with the highly reactive hydroxyl radicals formed by radiolysis, stimulating deep respiration. A similar process is well known for the degradation of organic matter with ultraviolet light (Benner and Biddanda, 1998; Moran and Zepp, 1997; Zafiriou, 2002).
Previous studies have shown the possibility of seawater flowing through cracks and voids of the basalt that underlies marine sediments, and thus act as a source or sink of dissolved substances (D'Hondt et al., 2004). Extrapolations of our oxygen profiles show the possibility of fluxes across the 
sediment/basalt interface (Fig. 5). In a scenario with higher respiration rates, which still provides acceptable fits of the data (Figs. 3 and 4), this could lead to fluxes from the basalt to the sediment. However, for Stations 3 and 4, where the piston core measurements reached close to the basalt, and hence the extrapolation procedure is the most reliable, such an efflux seems to be unlikely. The sediments from Stations 1-11 are geochemically similar and microbial cell numbers are comparable for these sites. Furthermore, high volumetric respiration rates are not supported by nitrate and alkalinity data (D'Hondt et al., 2009). Thus, a net flux of oxygen through the sediment into the basement at each site constitutes the most likely scenario, and leads to the question of possible sinks within the basalt. Oxygen could either be transported away by fluid flow within cracks and voids in the basalt (Fisher, 1998) or it could be reduced. One possibility would be the existence of a chemolitotrophic community within the basalt (Edwards et al., 2005; Stevens, 1997). Such communities were previously described for the flanks of the mid-ocean ridges (Ehrhardt et al., 2007; Huber et al., 2006) but their existence under the ocean basins remains controversial (Cowen et al., 2003). Drilling into the basalt under the SPG is necessary to further address this issue.

\subsection{Regional and global relevance}

Our sample sites cover a large part of the SPG. Therefore, we calculate that the total area of completely oxygenated sediments in this region is at least $10-15$ million $\mathrm{km}^{2}$, thus accounting for $3-4 \%$ of the global marine sediments. Murray and Grundmanis (1980) also found oxygen below $50 \mathrm{~cm}$ in equatorial Pacific sediments (hence outside of the SPG). Like the profiles obtained here, their oxygen profiles did not reach zero values but showed rather constant concentrations below an initial drop in the first several centimeters. Taking these findings into account, the fully oxygenated area is likely to be much larger, when including the deeply oxygenated sediment further north. Since the vast majority of all oxygen profiling measurements so far has been done in highly productive coastal areas or at mid-ocean ridges (Seiter et al., 2005; Wenzhöfer and Glud, 2002), it is likely that deep oxygen penetration also occurs in other low-productivity regions on earth, e.g. the North Pacific. Wenzhöfer et al. (2001) measured an in situ oxygen penetration depth of $\sim 25 \mathrm{~cm}$ in the Atlantic; comparable ex situ oxygen penetration depths were measured by Loeff et al. (1990). Estimated carbon mineralization rates from the subtropical Atlantic gyre are in the order of 1.5-2 $\mathrm{gC} \mathrm{m}^{-2} \mathrm{yr}^{-1}$ (Wenzhöfer and Glud, 2002) and compare well with rates from our sites (Table 1). However, they are based only on few in situ measurements. Considering only the central sites (Stations 6 and 7) rates differ by a factor 2, highlighting the extreme setting of the central SPG as an ultimate oceanic desert.

\section{Conclusions}

The aim of this work was to measure and analyze oxygen fluxes and consumption rates in sediments of the South Pacific Gyre, the most oligotrophic oceanic region on earth, and to obtain information about the magnitude and spatial organization of carbon turnover. While the oxygen flux to the sediment is not extraordinary low compared to other oligotrophic sites, we found strong indications for oxygen penetrating down to the basalt in nearly the whole region. Oxygen consumption rates decrease strongly within the first few centimeters of the sediment and oxygen that is not reduced within this upper sediment horizon is free to diffuse further downwards. Even in the deeper layers, there is still a small and constant flux of oxygen.

Acknowledgements. The authors would like to thank all participants of the KNOX-02RR cruise and the crew of the R/V Roger Revelle for their expert work. We particularly thank Franciszek Hasiuk and Andrea Stancin for the shipboard resistivity measurements used to calculate formation factors. Axel Nordhausen's technical assistance on board was most helpful. Without the work of Ingrid Dohrmann, Gabriele Eickert, Paul Färber, Volker Meyer, Ines Schröder and Cäcilia Wiegand this study would not have been possible; Moritz Holtappels helped with the analytical solution of the model. We thank two reviewers for their helpful comments; especially Filip Meysman's effort helped a lot to improve the manuscript. We thank the Integrated Ocean Drilling Program of the US National Science Foundation for funding the expedition. We also thank the Max Planck Society and the German National Science Program (DFG) IODP program for funding the lead author's participation in the expedition and for sponsoring our post-cruise research.

The service charges for this open access publication have been covered by the Max Planck Society.

Edited by: C. P. Slomp

\section{References}

Antia, A., Koeve, W., Fischer, G., Blanz, T., Schulz-Bull, D., Scholten, J., Neuer, S., Kremling, K., Kuss, J., and Peinert, R.: Basin-wide particulate carbon flux in the Atlantic Ocean: Regional export patterns and potential for atmospheric $\mathrm{CO}_{2}$ sequestration, Global Biogeochem. Cy., 15, 845-862, 2001.

Archer, D., Emerson, S., and Smith, C. R.: Direct measurement of the diffusive sublayer at the deep sea floor using oxygen microelectrodes, Nature, 340, 623-626, 1989.

Barnett, P., Watson, J., and Connely, D.: A multiple corer for taking virtually undisturbed samples from shelf, bathyal and abyssal sediments, Oceanol. Acta, 7, 399-408, 1984.

Behrenfeld, M. and Falkowski, P.: A consumer's guide to phytoplankton primary productivity models, Limnol. Oceanogr., 42, 1479-1491, 1997.

Bender, M. L. and Heggie, D. T.: Fate of organic carbon reaching the deep sea floor: a status report, Geochim. Cosmochim. Acta, 48, 977-986, 1984. 
Benner, R. and Biddanda, B.: Photochemical Transformations of Surface and Deep Marine Dissolved Organic Matter: Effects on Bacterial Growth, Limnol. Oceanogr., 43, 1373-1378.

Berg, P., Rysgaard, S., Funch, P., and Sejr, M.: Effects of bioturbation on solutes and solids in marine sediments, Aquat. Microb. Ecol., 26, 81-94, 2001.

Berger, W. H., Fischer, K., Lai, C., and Wu, G.: Ocean productivity and organic carbon flux. I. Overview and Maps of Primary Production and Export Production., University of California, San Diego, SIO Reference, 87-30, 67 pp., 1987.

Berner, R.: Early Diagenesis: A Theoretical Approach, Princeton University Press, 1st edn., 1980.

Betzer, P., Showers, W., Laws, E., Winn, C., Ditullio, G., and Kroopnick, P.: Primary productivity and particle fluxes on a transect of the equator at $153^{\circ} \mathrm{W}$ in the Pacific Ocean, Deep-Sea Res. A, 31, 1-11, 1984.

Blair, C. C., D'Hondt, S., Spivack, A. J., and Kingsley, R. H.: Radiolytic hydrogen and microbial respiration in subsurface sediments, Astrobiology, 7, 951-970, 2007.

Buckley, D. E., MacKinnon, W. G., Cranston, R. E., and Christian, H. A.: Problems with piston core sampling: Mechanical and geochemical diagnosis, Mar. Geol., 117, 95-106, 1994.

Claustre, H., Huot, Y., Obernosterer, I., Gentili, B., Tailliez, D., and Lewis, M.: Gross community production and metabolic balance in the South Pacific Gyre, using a non intrusive bio-optical method, Biogeosciences, 5, 463-474, 2008, http://www.biogeosciences.net/5/463/2008/.

Claustre, H. and Maritorena, S.: The Many Shades of Ocean Blue, Science, 302, 1514-1515, 2003.

Cowen, J. P., Giovannoni, S. J., Kenig, F., Johnson, H. P., Butterfield, D., Rappe, M. S., Hutnak, M., and Lam, P.: Fluids from Aging Ocean Crust That Support Microbial Life, Science, 299, 120-123, 2003.

D’Hondt, S., Jørgensen, B., Miller, D., Batzke, A., Blake, R., Cragg, B., Cypionka, H., Dickens, G., Ferdelman, T., and Hinrichs, K.: Distributions of Microbial Activities in Deep Subseafloor Sediments, Science, 306, 2216-2221, 2004.

D’Hondt, S., Spivack, A. J., Pockalny, R., Fischer, J. P., Kallmeyer, J., Ferdelman, T., Abrams, L., Smith, D. C., Graham, D., Hasiuk, F., Schrumm, H., and Stancin, A. M.: Subseafloor sedimentary life in the South Pacific Gyre, P. Natl. Acad. Sci. USA, 106, $11651-11656,2009$.

Dandonneau, Y., Vega, A., Loisel, H., du Penhoat, Y., and Menkes, C.: Oceanic Rossby Waves Acting As a "Hay Rake" for Ecosystem Floating By-Products, Science, 302, 1548-1551, 2003.

Daneri, G. and Quinones, R.: Undersampled Ocean systems: aplea for an international study of biogeochemical cycles in the Southern Pacific Gyre and its boundaries, US JGOFS Newsletter, 11, p. 9, 2001

Edwards, K. J., Bach, W., and McCollom, T. M.: Geomicrobiology in oceanography: microbe-mineral interactions at and below the seafloor, Trends Microbiol., 13, 449-456, 2005.

Ehrhardt, C. J., Haymon, R. M., Lamontagne, M. G., and Holden, P. A.: Evidence for hydrothermal Archaea within the basaltic flanks of the East Pacific Rise, Environ. Microbiol., 9, 900-912, 2007

Fisher, A.: Permeability within basaltic oceanic crust, Rev. Geophys, 36, 143-182, 1998.
Gehlen, M., Bopp, L., Emprin, N., Aumont, O., Heinze, C., and Ragueneau, O.: Reconciling surface ocean productivity, export fluxes and sediment composition in a global biogeochemical ocean model, Biogeosciences, 3, 521-537, 2006 , http://www.biogeosciences.net/3/521/2006/.

Glud, R. N.: Oxygen dynamics of marine sediments, Mar. Biol. Res., 4, 243-289, 2008.

Glud, R. N., Gundersen, J. K., Revsbech, N. P., and Jørgensen, B. B.: Effects on the benthic diffusive boundary layer imposed by microelectrodes, Limnol. Oceanogr., 39, 462-467, 1994.

Hammond, D. E., Mcmanus, J., Berelson, W. M., Kilgore, T. E., and Pope, R. H.: Early diagenesis of organic material in equatorial Pacific sediments: stoichiometry and kinetics, Deep-Sea Res. Pt. II, 43, 1365-1412, 1996

Huber, J. A., Johnson, H. P., Butterfield, D. A., and Baross, J. A. Microbial life in ridge flank crustal fluids, Environ. Microbiol., 8, 88-99, 2006.

Jahnke, R.: The global ocean flux of particulate organic carbon: Areal distribution and magnitude, Global Biogeochem. Cy., 10, 71-88, 1996

Jørgensen, B. B. and D'Hondt, S.: A Starving Majority Deep Beneath the Seafloor, Science, 314, 932-934, 2006.

Klimant, I., Meyer, V., and Kühl, M.: Fiber-optic oxygen microsensors, a new tool in aquatic biology, Limnol. Oceanogr, 40, 1159 1165, 1995.

Lin, L.-H., Hall, J., Lippmann-Pipke, J., Ward, J.A., Sherwood Lollar, B., DeFlaun, M., Rothmel, R., Moser, D., Gihring, T., Mislowack, B., and Onstott, T.C.: Radiolytic $\mathrm{H}_{2}$ in the continental crust: nuclear power for deep subsurface microbial communities, Geochem. Geophys. Geosyst, 6, Q07003, doi:10.1029/2004GC000907, 2005.

Moran, M. A. and Zepp, R. G.: Role of Photoreactions in the Formation of Biologically Labile Compounds from Dissolved Organic Matter, Limnol. Oceanogr, 42, 1307-1316, 1997.

Morel, A., Gentili, B., Claustre, H., Babin, M., Bricaud, A., Ras, J., and Tiche, F.: Optical properties of the "clearest" natural waters, Limnol. Oceanogr, 52, 217-229, 2007.

Murray, J. and Kuivila, K.: Organic matter diagenesis in the northeast Pacific: transition from aerobic red clay to suboxic hemipelagic sediments, Deep-Sea Res. Pt. I, 37, 59-80, 1990.

Murray, J. W. and Grundmanis, V.: Oxygen Consumption in Pelagic Marine Sediments, Science, 209, 1527-1530, 1980.

Pace, M. L., Knauer, G. A., Karl, D. M., and Martin, J. H.: Primary production, new production and vertical flux in the eastern Pacific Ocean, 325, 803-804, 1987.

Raimbault, P., Garcia, N., and Cerutti, F.: Distribution of inorganic and organic nutrients in the South Pacific Ocean - evidence for long-term accumulation of organic matter in nitrogen-depleted waters, Biogeosciences, 5, 281-298, 2008, http://www.biogeosciences.net/5/281/2008/.

Ras, J., Claustre, H., and Uitz, J.: Spatial variability of phytoplankton pigment distributions in the Subtropical South Pacific Ocean: comparison between in situ and predicted data, Biogeosciences, 5, 353-369, 2008, http://www.biogeosciences.net/5/353/2008/.

Rasmussen, H. and Jørgensen, B. B.: Microelectrode studies of seasonal oxygen uptake in a coastal sediment: Role of molecular diffusion, Mar. Ecol.-Prog. Ser., 81, 289-303, 1992.

Reimers, C. E., Fischer, K. M., Merewether, R., Smith, K. L., and Jahnke, R. A.: Oxygen microprofiles measured in situ in deep 
ocean sediments, Nature, 320, 741-744, 1986.

Reimers, C. E., Kalhorn, S., Emerson, S. R., and Nealson, K. H.:Oxygen consumption rates in pelagic sediments from the Central Pacific: First estimates from microelectrode profiles, Geochim. Cosmochim. Ac., 48, 903-910, 1984.

Revsbech, N.: An Oxygen Microsensor with a Guard Cathode, Limnol. Oceanogr., 34, 474-478, 1989.

Rutgers Van Der Loeff, M. M., Meadows, P. S., and Allen, J. A.: Oxygen in Pore Waters of Deep-Sea Sediments [and Discussion], Philos. T. R. Soc. A, 331, 69-84, 1990.

Sayles, F. L., Martin, W. R., and Deuser, W. G.: Response of benthic oxygen demand to particulate organic carbon supply in the deep sea near Bermuda, Nature, 371, 686-689, 1994.

Schabenberger, O. and Pierce, F. J.: Contemporary statistical models for the plant and soil sciences, CRC Press, 343 pp., 2001.

Schulz, H. and Zabel, M.: Marine Geochemistry, Springer, 1st edn., 2000.

Seiter, K., Hensen, C., and Zabel, M.: Benthic carbon mineralization on a global scale, Global Biogeochem. Cy., 19, GB1010, doi:10.1029/2004GB002225, 2005.

Skinner, L. C. and McCave, I. N.: Analysis and modelling of gravity- and piston coring based on soil mechanics, Mar. Geol., 199, 181-204, 2003.

Smith, K. L.: Benthic community respiration in the NW Atlantic Ocean: In situ measurements from 40 to $5200 \mathrm{~m}$, Mar. Biol., 47, 337-347, 1978.
Spinelli, G. A., Giambalvo, E. G., and Fisher, A. T.: Hydrologic properties and distribution of sediments, in: Hydrogeology of the Oceanic Lithosphere, edited by: Davis, E. E. and H. Elderfield, H., Cambridge University Press, 151-188, 2004.

Stevens, T.: Lithoautotrophy in the subsurface, FEMS Microbiol. Rev., 20, 327-337, 1997.

Suess, E.: Particulate organic carbon flux in the oceans - surface productivity and oxygen utilization, Nature, 288, 260-263, 1980.

Thamdrup, B. and Canfield, D. E.: Benthic respiration in aquatic sediments, in: Methods in Ecosystem Science, edited by: Sala, O. E., Jackson, R. B., Mooney, H. A., and Howarth, R. W., Springer-Verlag, New York, 1st edn., 2000.

Weiss, R.: The solubility of nitrogen, oxygen, and argon in water and seawater, Deep-Sea Res. A, 17, 721-735, 1970.

Wenzhöfer, F. and Glud, R.: Benthic carbon mineralization in the Atlantic: a synthesis based on in situ data from the last decade, Deep-Sea Res. Pt. I, 49, 1255-1279, 2002.

Wenzhöfer, F., Holby, O., and Kohls, O.: Deep penetrating benthic oxygen profiles measured in situ by oxygen optodes, Deep-Sea Res. Pt. I, 48, 1741-1755, 2001.

Zafiriou, O.: Sunburnt organic matter: biogeochemistry of lightaltered substrates, Limnol. Oceanogr. Bull, 11, 69-74, 2002. 